\title{
A Hairy State of Mind: Creativity in the Arabic Literary Imaginary
}

Wen-chin Ouyang

SOAS University of London

Thornaugh Street

Russell Square

London WC1H 0XG

UK

Email: wo@soas.ac.uk

\section{Abstract}

What is the body language of creativity? Poetry and madness are inexorably connected in the Arabic literary imaginary. Poetic inspiration in pre-modern Arabic writings is often portrayed as madness or magic, and poet as madman or magician. Poets and madmen, on occasions, share body language. Hair plays a key role in the visualization of the body language of creativity. This paper anchors its discussion of the ways in which pre-modern Arabic writings visualize the body in action at moments of creativity in Kitāb al-aghānỉs description of Jarir on the night he composed one of his most famous satires, and explores hair as a semiotic code that inheres the tension between grammar and ungrammaticality, reason and madness, imitation and originality in literary works.

\section{Hair and Poetry}

In a long anecdote Abū al-Faraj al-Iṣfahānī relates in Kitāb al-aghānīon the circumstances surrounding the composition of one of Jarī's most famous satires (hijā), which ends with the line, Fa-ghuḍda t-tarfa innaka min Numayrin, fa-lā ka ban balaghta wa-lā kilābā, hair plays a leading role in the portrayal of Jarīr (33-110/653-728) at both the moments of creativity and delivery. In this anecdote, the rivalry between Jarīr and his nemesis al-Farazdaq (38-114/732641 ) is escalated into a very public and "sectarian" affair, with Rā'ī al-Ibil (aka al$\operatorname{Ra}^{\mathrm{c}} \overline{\mathrm{i}}$ al-Numayrī, dates unkown) and more particularly his son, Jandal, at the forefront of the "poetic" or "verbal" battle between Jarīr's gang and al-Farazdaq's entourage. These two distant cousins, I mean Jarīr and al-Farazdaq, the two most famous Uamayyad court poets, seem to have taken the tribal lore of al-naqāid, their infamous exchanges of poetic lampoons and bantering, to a comical height.

The event takes place in Mirbad (Basra) over the course of two days. The anecdote sets up the event during the ascendance of Rāi al-Ibil as a "critic," who seems to prefer al-Farazdaq to Jarīr. Jarīr, puzzled by his position and attitude, decides to have a word with him privately. "Are you not amazed by this man," he says to his "entourage" (rijāl min qawmihi), "who prefers al-Farazdaq to me, when he [al-Farazadaq] lampoons his tribe while I praise them?" Jarīr makes up his mind to confront $\operatorname{Ra}^{\bar{c}} \overline{1}$ al-Ibil. So, he goes to Mirbad one day, on foot rather than on his mount, for he does not want anyone to know, and waits for Rā'ì al-Ibil to leave the assembly or circle (halqah), where he and al-Farazdaq hold regular 
meetings with their entourage (julasā'). At the moment the assembly disbands, he accosts $\operatorname{Ra}^{\mathrm{c}} \mathbf{i}$ al-Ibil, when sees $\mathrm{Ra}^{\mathrm{c}} \mathrm{i}$ al-Ibil coming his way, riding a mule, while his son Jandal follows on a pony with severed tail, accompanied by a man on foot asking him about one thing or another, he intercepts him, slaps with his left hand the forehead of his [Rāî̀ al-Ibil] mule, and says, "O Abū Jandal, your words are indeed heard! You do side with al-Farazdaq in a reprehensible way (innaka tufaddilu l-Farazdaqa 'alayya tafdilan qabịhan) even though I praise your tribe while he lampoons them and he is my cousin (ibn 'ammì). A little from you will go a long way. If we are mentioned, why don't you simply say they are both fine poets? Neither he nor I will reproach you [for saying this or taking this position]." In the meantime, Jandal catches up with his father, and he hits the back of his father's mule with his whip imported from Kerman, saying to his father, "I see that you are standing with a dog from the dog tribe as if you feared some evil will come from him." The mule kicks out, which startles Jarīr, and his hat falls on the ground. Rāī al-Ibil and Jandal walk away without a backward glance. Jarīr picks up his hat, wipes the dust off it, puts it back on and goes back to where he is staying dejected and angry.

That night, after the evening prayer, the story continues, Jarī goes up to his room on the second floor, orders wine to be sent up to him, and a lamp to be lit for him. This is done. He begins to hum (or mutter). An old woman hears him, goes up the stairs to see what is going on, and finds him naked, crawling on all four on his "bed" ( fa-idhā huwa yaḥbū 'alā l-firāshi 'uryānan li-mā huwa fïhi). She comes down the stairs and tells his companions, "your guest is mad (dayfukum majnūn!)." They tell her to mind her own business and send her away, saying "we know better what he is doing." Jarīr remains like this all night. When dawn breaks, he suddenly utters "Allāhu Akbar (God is Great)!" and recites the eighty lines that end with "Fa ghudda t-tarfa [...]." He waits until the morning, when he is certain that $\mathrm{Ra}^{\mathrm{c}} \overline{\mathrm{I}}$ al-Ibil and al-Farazdaq have sat down with their entourage in their assembly at Mirbad, then orders oil [for his hair] to be brought to him. He oils his hair-and he has beautiful hair-and gathers it, then orders his horse saddled. He rides [on his horse] all the way to the place where people give their salutations at Rā'i al-Ibil and al-Farazdaq's halqah. There, at the entry way to the halqah, recites his poem and leaves right away. Throughout his recitation, Rāî̀ alIbil and al-Farazdaq keep their heads bowed, and their entourage remain completely silent. As soon as Jarīr leaves, $\operatorname{Ra}^{\mathrm{c}} \overline{1}$ al-Ibil mounts his mule, rushes to where he is staying, tells his entourage to leave [town] right away, and without further ado escapes Basra himself. As soon as he reaches the campsite of his tribe, Jarīr's poem has already arrived and is being circulated among his tribesmen and women. As al-Iṣfahānī tells it, no man could have been fast enough to bring the poem to the tribe, of course, but then Jarīr had his staunch allies from among the Jinn (wa inna li-Jarīr la-ashyā'an min al-jinn), who, if we are to take a hint from the clue he drops for us, his readers here, were fast at work in making sure $\operatorname{Ra}^{\mathrm{c}} \overline{\mathrm{I}} \mathrm{al}-\mathrm{Ibil}$ got his come-uppance in no time at all. ${ }^{1}$

There are quite a few tale-telling signs of the role of material world and objects in giving texture and nuance to the fabric of the literary imaginary in this anecdote. They partake in the visualizing capacity of word, and draw a picture of the events, the two confrontations in this anecdote-Jarir's initial secretive, 
humbling encounter with Rāì al-Ibil's at some "distance" from the entrance to the latter's halqah (fa-kharajtu ata'arraḍu lahu li-alqāhu min hiyālin haythu arāhu yamurru idhā inșarafa), where his presence would go unnoticed, and his eventual triumphant public delivery of his take-no-hostage satire at the very entrance of the halqah-in a way that parallels as well as confirms the trajectories of the narrative, in this case, the movement of the storyline from Jarir's humility at the beginning of the anecdote to his triumph in the end. The organization of two events around "secrecy" and "openness" already gives us a glimpse of the spatial hierarchy at work in the story. While the "secrecy" points to "humiliation" "openness" anticipates "victory." The mounts, for another example, anticipate this transformation of Jarīr from defeat to triumph. In the first half of the anecdote, we see the three figures positioned in this hierarchy: Jarìr on foot, Jandal on a pony, and $\mathrm{Ra}^{-} \overline{1}$ al-Ibil on a mule. In the second half of the anecdote, we see Rāî al-Ibil sitting down while Jarīr is on a horse; in fact, he most likely recites his poem on horseback as well. If you look at the three mounts together-pony, mule and horse-you will see that Jarīr will be triumphant. In the hierarchy of animals-and this hierarchy can be reconstructed from Arabic dream literature-whereby horse is not only taller but also nobler. Similarly, the hair, though making only a very brief appearance, has much to say about the Arabic literary imaginary.

I draw attention to the juxtaposition set up in the anecdote between the states of dress in the two halves of the anecdote: Jarīr is "naked" while composing, and "fully dressed," possibly "in his best," while delivering his devastating poem. His hair may not be mentioned in the first half of the anecdote, but that it may have been let down and loose could be deduced from the second half of the anecdote, when he "orders oil [for his hair] to be brought to him, oils his hair, and gathers it up." The function of hair in this anecdote, it seems, is neither sociological nor anthropological. It is not an expression of Jarīr's identity, nor is it a part of ritual cleansing. The hair rituals (involving oiling and gathering up) in the second half of the anecdote may be taken as a sign of the recitation of poetry as a ritual performance in Kitāb al-agāhnīin the same sense of what Andras Hamori speaks of Abū Nuwās as a "ritual clown," but what of the loose hair in the first half of the anecdote? Its association with states of undress and dress points to its sociological not theological dimension. Hair is not considered theologically a part of the body and it is more often than not treated sociologically like dress. Hairdos make statements about a person's position, cultural or ideological, in society, or even the social space he is in. It is possibly as a sign of being at home (in a private space), as we see Jarin in his room tucked away upstairs in the first half of the anecdote, and of appearing in public to deliver a "ritual" performance in the second half. However, its association with madness, junūn - the old woman who sees Jarìr in the middle of his creative humming says to his entourage: "dayfukum majnūn"-points to something else, to it being, I will argue, a part of a semiology of creativity in the Arabic literary imaginary.

In the following, I pursue the sign of the hair and look at the ways in which it, where it appears Arabic writings together with its attendant association, reveals to us how literary creativity and its machinery are 
understood, expressed and grappled with in the Arabic literary imaginary. With focus on the three 'concepts' triangulated in the Jarīr anecdote: madness, dress, including hair, and poetry, I begin with the hints dropped in the anecdote on the relationship between hair and dress, and between the state of these at a moment of creativity and madness, and go on to think about what madness (junūn) in Arabic writings says about disciplined thought and language, structured around reason ( $a q I$ ) and where it resides, on the head ( $r{ }^{\prime} s$ ) and in the mind (dimāgh), with particular reference to Ibn al-Jawzī, and therefore, about literary creativity in which language is necessarily implicated. I then turn to another meaning associated with madness and mad hair: tyranny, and examine the implication of linking tyranny to madness in thinking about grammaticality and defamiliarization in poetic language. I explore this and the ways in which madness, language and tyranny collude, collide and diverge in the Majnūn legends, implicit in the states of the love mad poet's, body, hair and tongue as related also by al-Ișfahānī in Kitāb al-aghānī, to give expression to a certain conceptualization of creativity, albeit rather under-articulated and only in relation to poetry. Hair, as a sign in the Arabic semiology of creativity, is the site of the configuration of Arabic imaginings of the machinery of creativity built on a three-way collaboration of language (poetry), reason (mind) and society (delivery and reception), and at the same time of the unravelling of the very fabric of these imaginings as necessarily stifling and counterproductive and must be resisted, overcome and transcended.

\section{Hair and States of the Mind: From Reason to Folly and Madness}

Madness, junūn, in Arabic lexicography is a description of the diminished capacity of reason (nuqșān al-'aqI) when the workings of reason ('aqI) are concealed (sutira) or engulfed in darkness. Majnūn is someone who has lost his reason, 'aql, or is possessed by a genie, jinn. A genie is so called because it lurks in the dark and is invisible to the eye. Junūn is the extreme antonym of 'aql. 'AqI is in turn defined as the innate ability or intelligence to curb, forbid (hajror hijr) or stop an action (nahy), particularly that which is driven by desire, or better, passion (hawa) . It is a kind of intelligence that is the opposite of humq, hamāqah, or folly. In his discussion of a sleuth of malfunctions in the 'aqlin Akhbār alhamqā wa l-mughaffalīn, Ibn al-Jawzì relates hamāqah to notions of the stagnation of the market, "ma'khūdhah min hamaqat al-sūq idhā kasadat."2 A person of stagnant mind or opinion (kāsid al-'aql wa l-ra'y) should not be consulted on matters of war. ${ }^{3}$ He gives the example of al-baqlah al-hamqā'that grows where it will be washed away or eaten by a camel ${ }^{4}$ and, needless to say, gets washed away or eaten. Humq, more precisely, means using a wrong means to achieve a sound end, in the same way as taghfil: "ma'nā al-humq wa l-taghfil huwa al-ghalat fi l-wasilah wa l-țarìq ilā al-mațūb ma'a sịhhat al-maqsūud." ${ }^{5}$ It is differentiated from junūn, which here denotes erring in both purpose and means: "fa-innahu 'ibārah 'an al-khalal fì l-wasìlah wa l-maqșūd jamī‘an."6

Such deficiencies in 'aql have manifest physical and behavioural symptoms. In the fifth chapter of Kitāb al-ḥamqã wa l-mughaffalinn devoted to the attributes of the ahmaq, or fool (Fì dhikr sifät al-ahmaq), Ibn al-Jawzì speaks of both sets of attributes, appearance, "min haythu l-șürah," and conduct, "min 
haythu l-khișāl wa l-af āl," in the same breath, treating them as parts and parcels of the same thing. A composite picture of the fool emerges from an amalgamation of quotations harvested from diverse sources, from Greek medicine and the Torah to pre-Islamic and Islamic adab. These have in common that 'aqI resides inside the head, ra's, in the dimāgh, "mawdi' 'al-'aql al-dimāgh," 7 rather than in the heart, $q a l b$, as it is alternatively theorized on different occasions often informed by the Qur’anic verse (Hajj 46): "fa-takūna lahum qulübun yufakkirūna bihā (and they have hearts through which they think)." 8 The shape of the head is a sure sign of the state of mind, of 'aql. And, by extension, what one does to the head, including hair, is also a clear sign of the quality of the mind, of 'aql.

"If the head is small and ill-shapen," Ibn al-Jawzī begins his enumeration of the characteristics of the fool with a quotation, which he attributes to philosophers or wise men, "qāla ba'ḍ l-ḥukamā'," who see that "idhā kāna Ira'su saghiran wa radī'a l-shakl" is "a sure indication that the mind is in a vile shape", or "dalla 'alā radāatin fi hay’ati l-dimāgh." 9 He then goes on to "quote" at length from Galen on what physical attributes say about the quality of man's mind and conduct. "The smallness of the head is undoubtedly an indication of the ill shape of the mind." Similarly, "[a] short neck indicates that the mind is weak and feeble," and "a man whose built lacks symmetry is vile even in his ambition and reason." 10 Bulky body, small head, round face, fleshy forehead, and thick neck, as well as chubby cheeks, plump feet, round head and [bushy] beard are all signs of a man's evil character. ${ }^{11}$ The shape, colour and movement of the eye are dead giveaways of the quality of a man's mind. Big but shifty eyes tell us that a man is lazy, good for nothing, greedy, foolish and a womanizer. ${ }^{12} \mathrm{~A}$ man is foolish when his eyes resemble those of a cow, or are protruding despite his heavy lids, ${ }^{13}$ or are broken and of unnatural colour, ${ }^{14}$ for example. A man whose neck is long and thin is a fool and coward. A man with thick full nose is lacking in comprehension, thick lips foolish and coarse, and thick round face or ear ignorant. ${ }^{15}$ Beautiful voice, heavy build, and height are all signs of dense understanding, stupidity and ignorance. ${ }^{16}$

Hair is another tale telling sign. Thick hair on shoulders and neck is an indication that a man is foolish and reckless, and on chest and belly haplessness. ${ }^{17}$ Beard, if bushy (above) or long, says the same, that a man is foolish. The length of the beard is unmistakably a mark of foolishness, for-and here Ibn al-Jawzi turns to the Torah for supporting evidence, "the spring (makhraj) of the beard is the brain (dimāgh), and whoever grows his beard long diminishes his brain, and when his brain is diminished his reason ( $a q I$ ) is weakened, and when his reason is weakened he becomes foolish (ahmaq)."18 $\mathrm{He}$ then looks to "ancient wisdom" for further proof. "Philosophers (al-hukamā) do say that folly (humq) is the fertilizer ( $\operatorname{sama\overline {d}}$ ) for beard, and that whoever grows his beard increases his folly," 19 Ibn al-Jawzi tells us, and that in addition to the habitual link between long beard and folly, ancients such as al-Ahnaf ibn Qays associated long beard with stupidity (riqā'ah), Mu'awiyah feeble-mindedness (sakhāfah), and 'Abd al-Malik ibn Marwān dull-wit (kawsaj fí 'aqlih; literally, missing teeth in the mouth of his brain). ${ }^{20}$ 
Ibn al-Jawzì does not discuss the hair on top of the head. The link between beard and the size of the brain as well as the quality of the mind, which are located in the head, does give us a clue as to the relevance of hair to the state of the mind. Hairdos, what is done to the head, were considered up to the turn of the $20^{\text {th }}$ century as manifestations of the quality of the mind. In the January 1897 issue of al-Muqtataf one of the most influential Arabic "scientific and cultural" journals at the time founded by Lebanese Ya'qūb Șarrūf (1852-1927) and Fāris Nimr (1856-1951) in 1876, devotes a full article to how the ways in which people dress their hair reveal their rank in 'aqland by extension civilization, "Azyā' al-nās fì libās al-ra's." This article begins in the same vein as Ibn al-Jawzī's treatise on passion, Dhamm al-hawā (In Censure of Passion), juxtaposing reason ('aql) to passion (hawa) , but shifting focus from conduct to appearance, more particularly, to headgear and hair paraphernalia. "Love for distinction is instinctual among men and they turn to it when passion overcomes reason (kullamā ghalabat al-ahwā'al- ‘uqūl). Stripped naked all men may look the same but of course they differ in what the minds are capable of (quwā 'uqülihim) and what the hearts demand (mațālib nufüfusihim). This difference [among men] becomes even pronounced dependent on how they respond to what occurs to them. If they preoccupy their minds with important matters, their attention will be turned away from their appearance; otherwise many would focus on how to make their appearance give them the distinction they crave in society, often at the expense of intellectual and cultural pursuits that would have similarly given them social distinction (mumayyizāt 'aqliyyah wa adabiyyah). Scientists and philosophers, who search for the truth, and manufacturers and businessmen, who seek an honest living, dress simply-and only to protect themselves from the cold and the heat-so as not to be hindered in their movement, whereas the

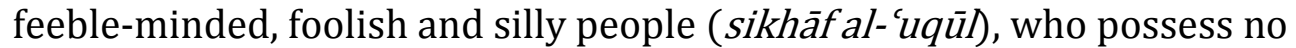
knowledge, virtue or money to distinguish them, adorn themselves with loud dress and decoration so as to be seen from miles away. ${ }^{21}$ If we abide by this logic, that simplicity in dress speaks for 'aqland ostentatiousness sukhf, then it follows that the savages (mutawahhishshün) dress more extravagantly than the civilized (mutamaddinūn), and men more simply than women. ${ }^{22}$

The rest of the piece comprises visual representations of heads and attendant hairdos and headgears from around the world clustered into three tableaux each followed by commentary. In the first (figure 1 below), native American medicine men (appearing in the column on the right) are identified and judged as: "the appearance of the medicine men (atibbā) of that lowly nation (al-ummah al-haqüirah) [i.e. the American Indians] signal their feeblemindedness (sakhāfat 'uqūlihim) and it will be impossible for them to be on par or compete with the European nations." 23 On the top of the left column is a Japanese scholar whose simple functional hat protecting his broad forehead from the sun gives the impression of his substance as a man from a nation that seeks truth not embellishment (al-ummah al-yabāniyyah allatī tațlub al-haqā̄iq lä l-zakhāriff). ${ }^{24}$ Below him is a Chinese merchant whose frilly hat tells us that the Chinese are in general profit seeking and at the same time ostentation loving. This class of Chinese merchants are contrasted to the Chinese peasants, whose head appears immediately below. The hair neatly gathered on top a Chinese peasant head is said to signal that Chinese commoners ('āmmat ahālì al-șissin) 
are serious and hardworking who devote their efforts to earing their livelihood and have no time for frivolous pursuits (al-ihtimām bi l-sakhā'if́). ${ }^{25}$
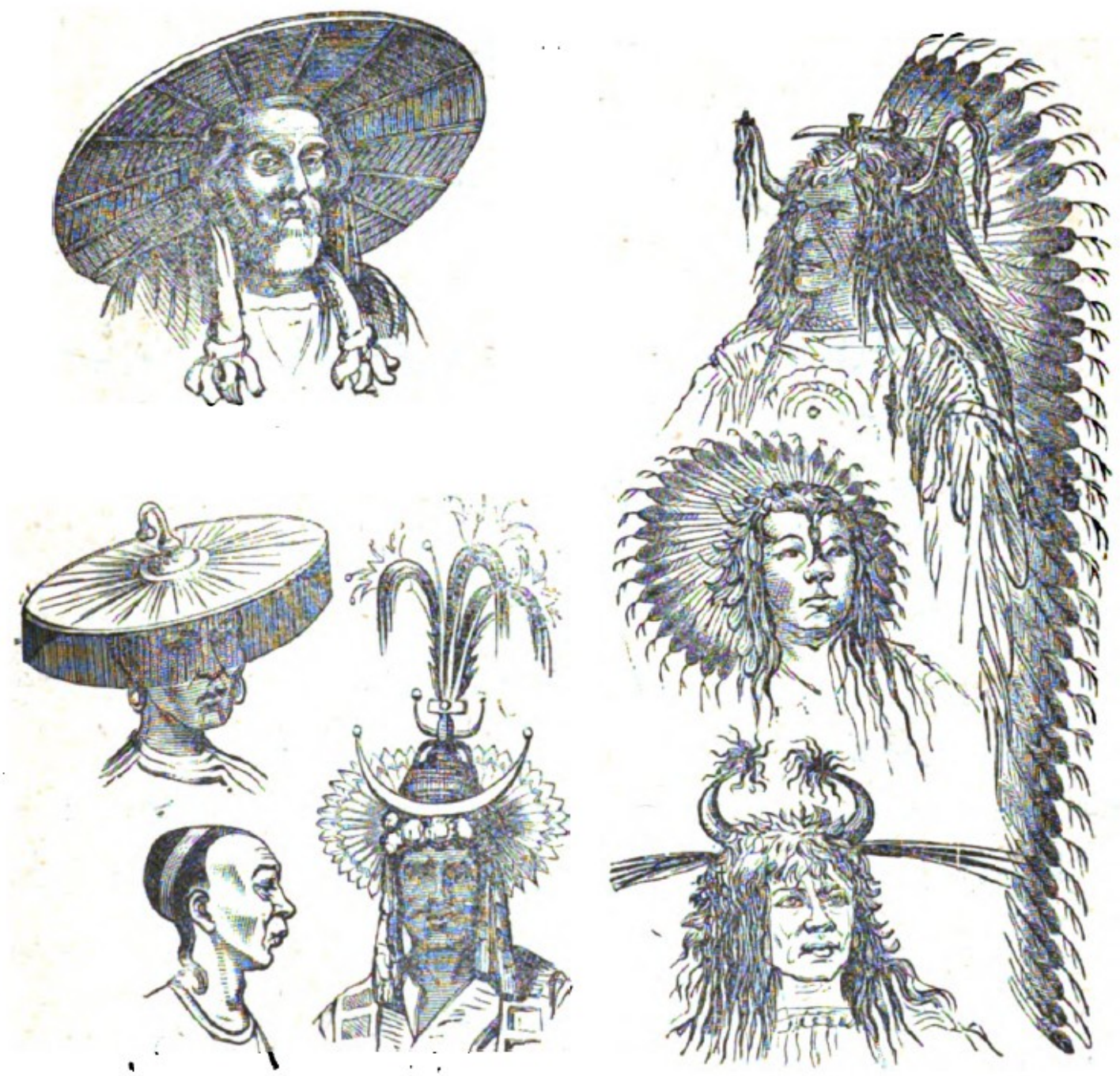

Figure 1

An Algerian in the following tableau (second head on the right in figure 2) is expressive of the dignified bearing of Arabs (al-hay'ah al-'arabiyyah alwaqürah), conveyed in his face, beard and veil, and this despite his over-the-top hat. ${ }^{26}$ 


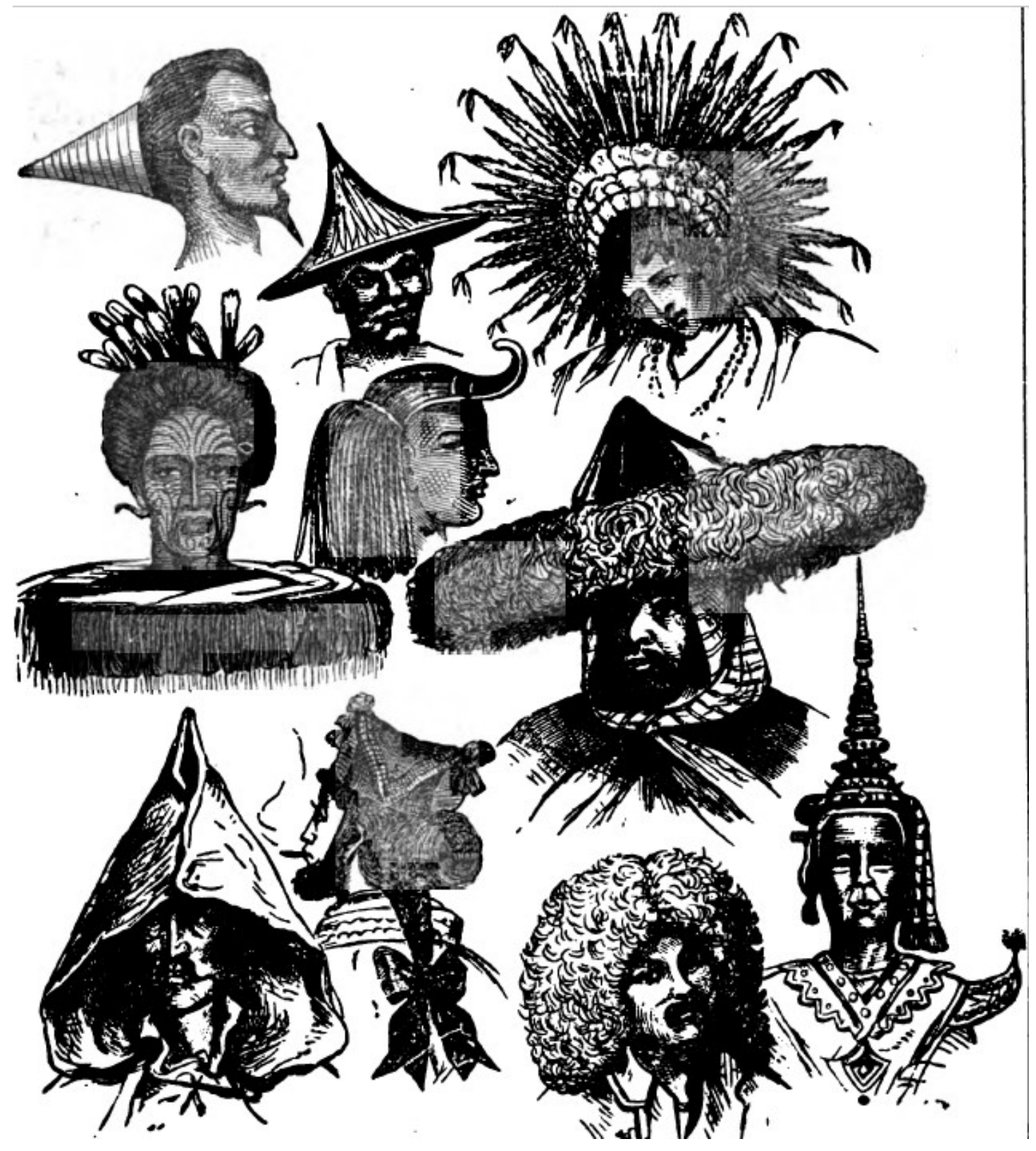

Figure 2

The third tableau (figure 3) provides five examples of dignity: an Eastern Orthodox religious man (top right) next to an Ottoman soldier (on his left), a priest from New Zealand (on his further left), and an Egyptian notable (below him) next to a Tatarian soldier. The exception is an African tribal chief, which the article describes:

Next to this Tatarian soldier is the picture of a feeble-minded (or silly) African king, who trimmed his beard so thin that it looks like the tail of a lizard, and who wore on his ears ivory sticks, forehead bull horns, and head a tower sprouting [kinky] locks and braids. All of these are not intended to protect him from heat or cold; rather, they are meant for him to distinguish himself [in importance and rank] from those below him in 
status but above him in mind (al-imtiyāz 'alā alladhīna tậtahu maqāman wa fawqahu 'aqlan). ${ }^{27}$

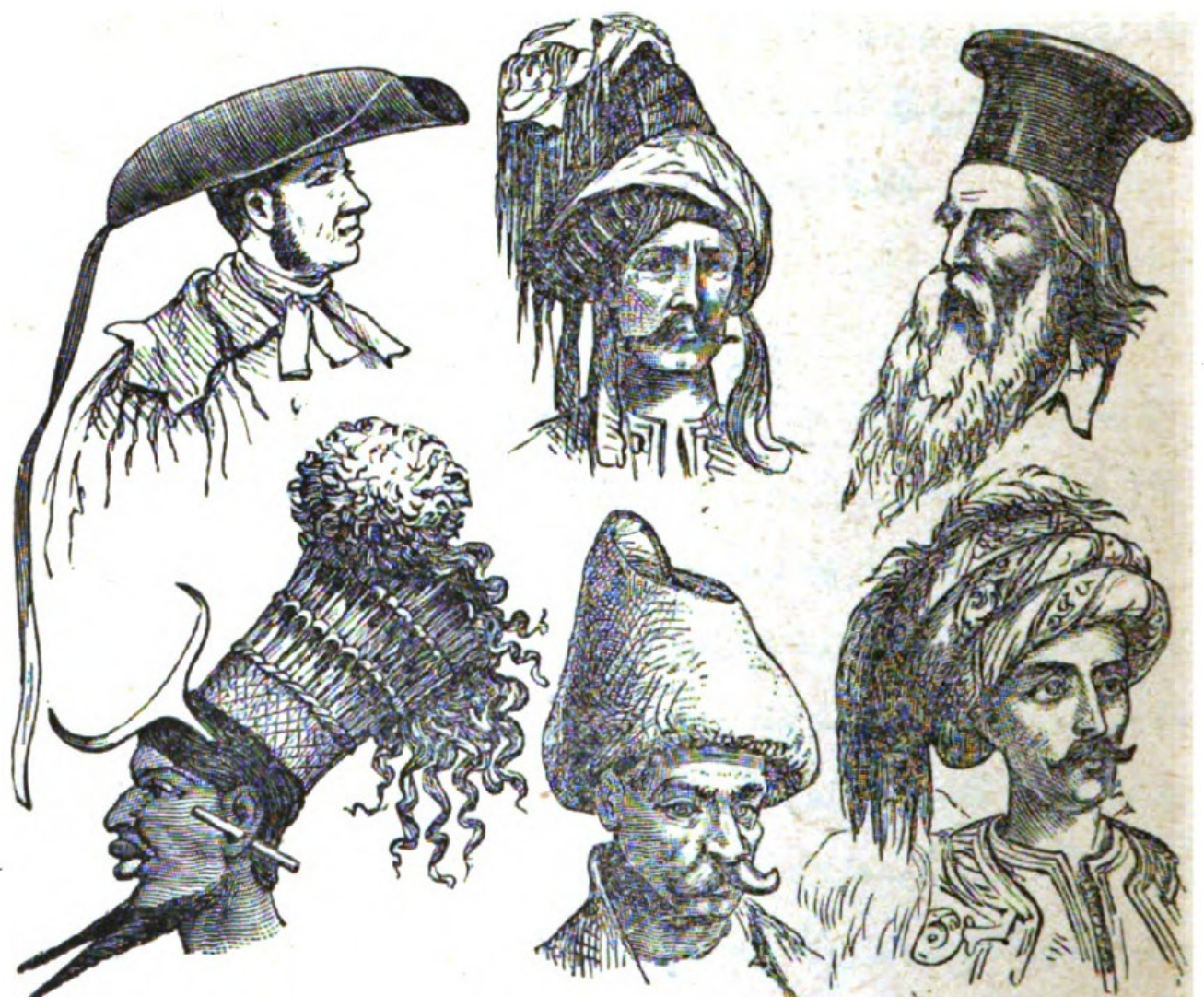

Figure 3

Cultural and literary historians will have a field day tracing the origins of these racist discourses to European travel writing, taking a cue from the clue dropped on a certain Langston mentioned in the article as having travelled across East and West Africa in 1855 and drawn the pictures of African heads reproduced here, to interrogate Orientalism as well as unpack the intersection between orientalist scholarship and the early modernist Arabic discourses on civilization and culture. This aspect of the article does not interest me. Similarly, I have no purpose in tracing and authenticating the biblical, Greek and Persian "quotations" in Ibn al-Jawzì's discourses on the relationship between physical appearance and the quality and state of the mind. I rather see these "quotations" as an integral part of the fabric of Arabic writings in which the echoes of "foreign" ideas and discourses point to resonance, even sympathy, and more importantly universality of these. Hair, as an extension of the head is, like beard, taken as a symptomatic sign of the quality and state of the mind. In the long anecdote on Jarīr from Kitāb al-aghānī I discussed earlier, hair performs precisely this function. It more particularly reveals the state his mind is in on three occasions: humility and expectation in the first as he stands waiting his hair neatly tugged in by his hat (qalansuwah); creative madness on the second as he gets naked, crawls on all four, lets his hair down and composes his poem; and 
determination and triumph on the third when he delivers his poem with his oiled and gathered hair. Hair's association with madness, here, particularly of a creative moment, and control, here, of determined performance, sets Jarīr's story apart from those related by Ibn al-Jawzī and in al-Muqtataf. These two associations in the Arabic literary imaginary locate creativity and its machinery, as I will show, in the interstices of the ebbs and flows of 'aql, whether we think of it as reason or mind, between madness and control, the latter of which is often represented as tyranny.

\section{The Hair Paradox: Madness and Tyranny}

In a semiology in which poetry (shi $r$ ) is inexorably connected to magic (sihr), genies (shayātīn al-shu'arā') and prophecy (tanabbu'), even of soothsaying (takahhun), which are all in turn linked to realm of knowledge beyond the reach or control of 'aql. 'Aqlin Arabic lexicography as we have seen is the ability to curb, forbid and stop passion, and one of its derivatives, 'iqāl, is the headband that holds the headgear in its place, therefore, hair tidily together. It is no wonder that madmen, magicians and poets are always portrayed with wild long hair and genies often with horns on their heads. In this specific context, the uncanny similarity between the anecdote about Jarīr in Kitāb al-aghānī, and those about Majnūn Laylā, also in Kitāb al-aghānī, is interesting. It is even possible to track the progression of Majnūn's state of mind, from "sanity" to "madness," through the states of his hair and dress, until his humanity, as a social being, completely disappears and he becomes pure poetry.

In the rather unwieldy storyline of Majnūn's madness woven together by al-Ișfahānī in Kitāb al-aghānī from the zigzagging, repetitive, overlapping, differing, and even conflicting anecdotes, it is possible to reconstruct a biography of Majnūn, and particularly of his madness, if we were to follow the thematic structure of a modern biography, in a linear progressive fashion as follows: Majnūn meets Laylā and they fall in love, Majnūn composes poetry on his love for Laylā and meets with censure from her family, Majnūn asks for Laylā's hand and is refused, Laylā marries another man and Majnūn goes mad, Majnūn forsakes the company of men and spends the rest of his days wandering the desert, living amongst the gazelles, and composing poetry pining for Laylā until he hears of Laylā's death and he himself dies. The anecdotes are packed with details on the changes occurring in his appearance, in his body, hair and dress, as he progresses from one stage of the story to the next.

Qays ibn al-Mulawwah was, according to his father, "the most handsome, charming and knowledgeable of poetry among the youth [of the tribe] (wa kāna ajmalahum wa azrafahum wa arwāhum li ash ār al-'arab)." ${ }^{28}$ When we first encounter him, he is a model of fashion and tidiness. The two anecdotes attributed to Hishām ibn al-Kalbī relating the crucial encounter between the two lovers describe the appearance of Qays as he approaches Laylā in the company of a group of female friends as, "he came towards them riding a noble camel and wearing two robes fit for kings (aqbala dhāta yawmin 'alā nāqatin karìmatin lahu wa 'alayhi hullatān min hulali l-mulūk)," 29 and "one day he went out riding a camel [...] He was wearing two splendid robes, a waist coat and a tall hat ('alayhi ḥullatāni luhu fākhiratāni wa taylasāni wa qalansuwah)." 30 His appearance, or 
beauty and perfection (jamāluhu wa kamāluhu), ${ }^{31}$ attracts the women's attention. They invite him to join them without hesitation. He even slaughters his camel to feed them. Layla falls in love with the dashing young man then and there and the rest is history.

However, as Qays progresses into madness, he loses his mount, sheds his clothes, lets his hair loose, forsakes human company and consorts with the animals. In other words he goes wild, or tawahhasha in Arabic. ${ }^{32}$ The following description of his physical state is given on one occasion [most likely after he has gone mad] when he hears the line of poetry Laylā composed on their initial behaviour towards each other (we both pretended to people that dislike each other when we are in reality deeply in love) sung: "He fell on the ground in a faint. By the time he returned to consciousness he had lost his mind. No sooner did he put on his clothes than he would tear them, and he walked around naked, wallowing in dirt and collecting bones around him." 33 Or when he is disappointed in securing his match with Laylā: "even before he went wild (illā annahu ghayr mustawhish), he isolated himself from society, tore any clothes put on him, went around naked, delirious, drawing lines on the sand, playing with dirt and stones." 34 Or after he was taken on a failed pilgrimage to seek God's help in curing him of his mad love for Laylā: "he wandered aimlessly in the desert with wild beasts, ate only what grew in the wild, drank only from the springs the gazelles frequented, and the hair on his body and head grew to such an extent that the gazelles and wild beasts no longer saw him [as a stranger] and rejected him (wa țāla sha'aru jasadihi was ra'sihi wa alifathu l-ẓibā'u wa lwuḥūshu fa kānat la tanfiru minhu)." 35 Or when a certain Nawfal ibn Musāhiqiq spied him in a herd of gazelles in the desert he found that Majnūn's "hair had fallen around his face (tadallā sha'ruhu 'alā wajhihì)" so that Nawfal recognized Majnūn only with great difficulty. ${ }^{36}$

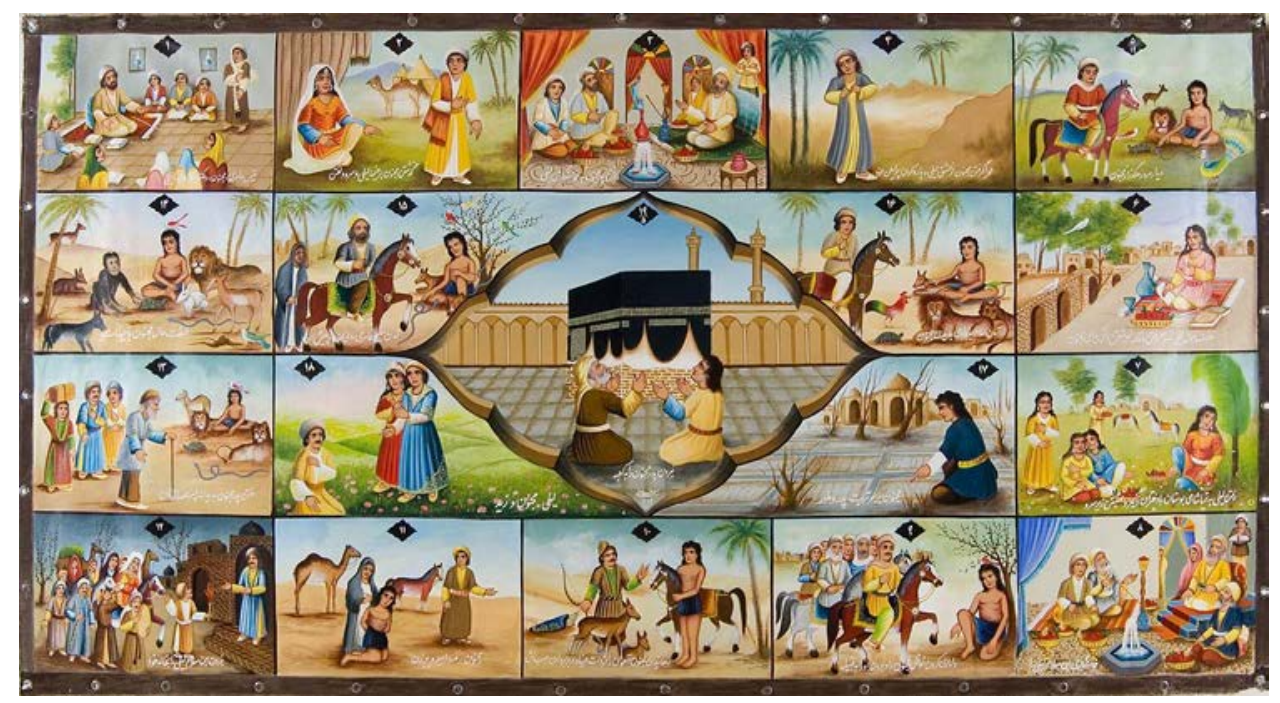

Even in his madness, Majnūn remembers Laylā, in fact he sees her everywhere, even mistaking gazelles for her, and spews love poetry on his love for her. He has in common with Jarīr, at least in Kitāb al-aghānī, madness, junūn, as a means to poetic inspiration and composition. Memorable poetry is the product of madness. The difference between Jarīr and Majnūn is that madness is temporary for Jarīr whereas it is a permanent state of mind for Majnūn. Madness 
is here, whether in regards to Jarìr or Qays, the source as well as instrument of creativity. Junūn, as I have already suggested, is the antidote of 'aql, in Arabic wirings. If ' $a q l$, whether it denotes reason or mind or sanity, is in contrast the source and instrument of control, of thought and conduct, and more importantly, of language, poetry, as the ultimate expression of creativity in Arabic writings, is necessarily, more often than not, seen as rebellion. Majnūn, the iconic love mad figure and the legends constructed around him, as As'ad Khairallah has shown, is an Arabic cultural statement of revolt against a patriarchal social structure founded on an epistemological system that deploys woman's honour to control not only individual conduct, symbolized by the freedom of both men and women to desire and love, but also freedom of expression, epitomized by love poetry. ${ }^{37}$ Her father's refusal of Qays as a suitor for Laylā, his imposing on her a husband to whom she is indifferent, and his turn to an unnamed "sultān" to impose a "restraint order" on Qays—the sulțān makes shedding Qays's blood lawful should he ever come near Laylā—can all be taken symbolically as signs of a tyrannical regime of power.

I want to move from sociology and epistemology to semiology and look at the ways in which hair and its visual representations, whether through word or image, speak to us of the tripartite tyranny of society, thought and language. If we take a cue for from the anecdote on Jarīr, we are able to see 'aqlas equivalent to tyranny when it exerts its control to extremity. Here, 'aql is associated with control visualized through Jarīr's hair and headgear. When Jarīr oils and ties his hair, puts on his best clothes, and rides his horse, he regains the control of his situation, in fact, gains the upper hand as he delivers his devastating satire. Tidy hair comes with victory, with control. Wild hair understandably signals defeat, loss of control. We already catch a glimpse of this early in the visual representation of anecdote when Jandal knocks Jarī's qalansuwah off his head, "fa-ramahatnī ramhatan waqa'at minhā qalansuwatī"38 Jarīr bends down to pick up his hat, wipes the dust off it, and puts it back on his head, "fa akhadhtu qalansuwatī wa masaḥtuhā thumma a'atuhā 'alā ra'sī," 39 and Rā'ī al-Ibil sees that as an omen of something awful to come, "amā wallāhi laqad țarahta qalansuwatahu tarhatan mash'ümah." 40 That this "accident" of the hat is felt by Jarīr as "insult" is confirmed in his remark that if Rā'i al-Ibil had stopped [to speak to him] he would not have made a big deal of it. ${ }^{41}$ This image of humiliation and loss of control-losing the headgear from the head-is duplicated in the Majnūn anecdotes-he sheds all his clothing, including his qalansuwah, as he goes more deeply into madness-and is supplemented with the image of him letting his hair go completely wild, long and loose, uncut and unkempt. Paradoxically, "hair-gone-wild" comes to be symbolic of the defeat of tyranny, of tyrannical regimes of power.

This paradoxical visual representation of headgear and hair as expression of control-and control can be a form of tyranny if pushed to the limit as I have already explained-and its defeat, or fall of tyranny, finds resonance even in cinematic visualisation of tyranny and the fall of tyrants today. Tyranny is madness, and tyrants having tyrannical fits are formulaically represented visually as men or women hopping mad, stomping about with their hair loose, wild and flying in all directions. This very visualization of tyranny having a 
temper tantrum coincides with the very moment of its total defeat. One eloquent example is the visualisation of the king of Liang at the moment of his transformation from a total despot to a dethroned monarch in the Chinese 2016 television historical drama, Nirvana in Fire. Liang is a terror of a king and rules his kingdom, court and harem, with an iron fist. He allows no difference of opinion let alone dissension. He manipulates, turns his officers, as well as wives and concubines, against each other in order to maintain his omnipresent authority. He is quick to execute, even his favorite son, and wipe out an entire army led by his loyal friend and ally, at a whisper of conspiracy against him. The story begins when one of his victims returns to the capital to seek justice. Lin $\mathrm{Shu}$, a young general, whose father was the kings's best friend and most senior army general, has survived a horrendous massacre unleashed by Liang on them on the frontline at the very moment they were completely spent, having just defeated king's most powerful enemy, returns to his homeland to put into place an elaborate plan for restoring his family honor. It ends with his triumph. He forces Liang to order the retrial of the former rebels, which would reveal the truth of their loyalty to the king and unravel the conspiracy behind their condemnation and execution. The events come to a head at their final meeting at court at king's lavish birthday celebration, when the king is presented with hard evidence and confronted by his crown prince and entire court's determination to not yield to his temper tantrum. As he comes to the realization that he is now completely isolated, not able to even command his own security guards to do his biddings, he tears his royal robe off his back, grabs his sword, and staggers off his throne to confront his son, the crown prince, and the officers of his entire court, then he falls. His "crown" falls off his head, and his hair goes out of control.

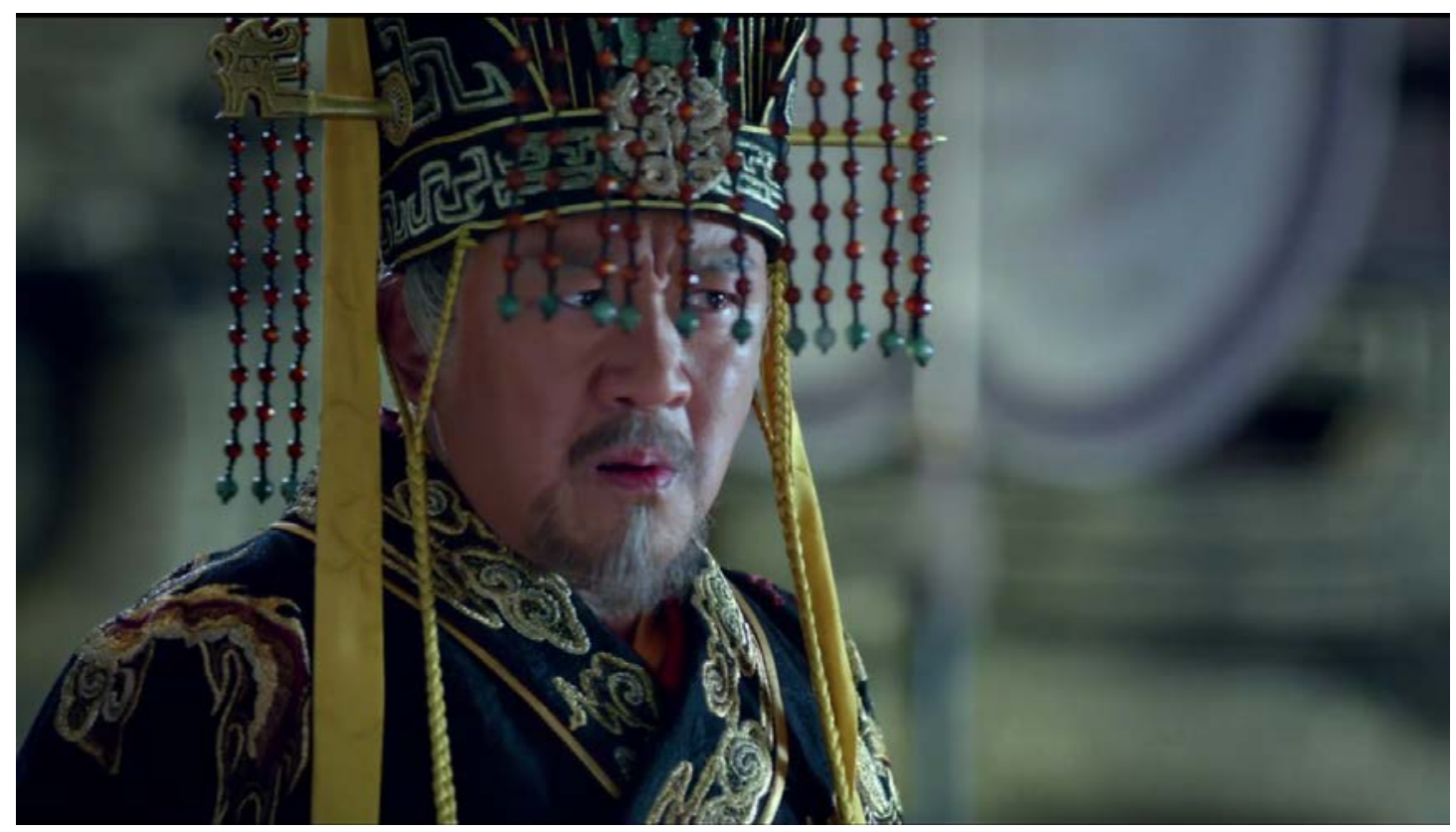


This is the accepted version of a forthcoming article that will be published by Taylor \& Francis in Al-

Masaq: Journal of the Medieval Mediterranean: http://www.tandfonline.com/loi/calm20

Accepted Version Downloaded from SOAS Research Online: http://eprints.soas.ac.uk/24479/
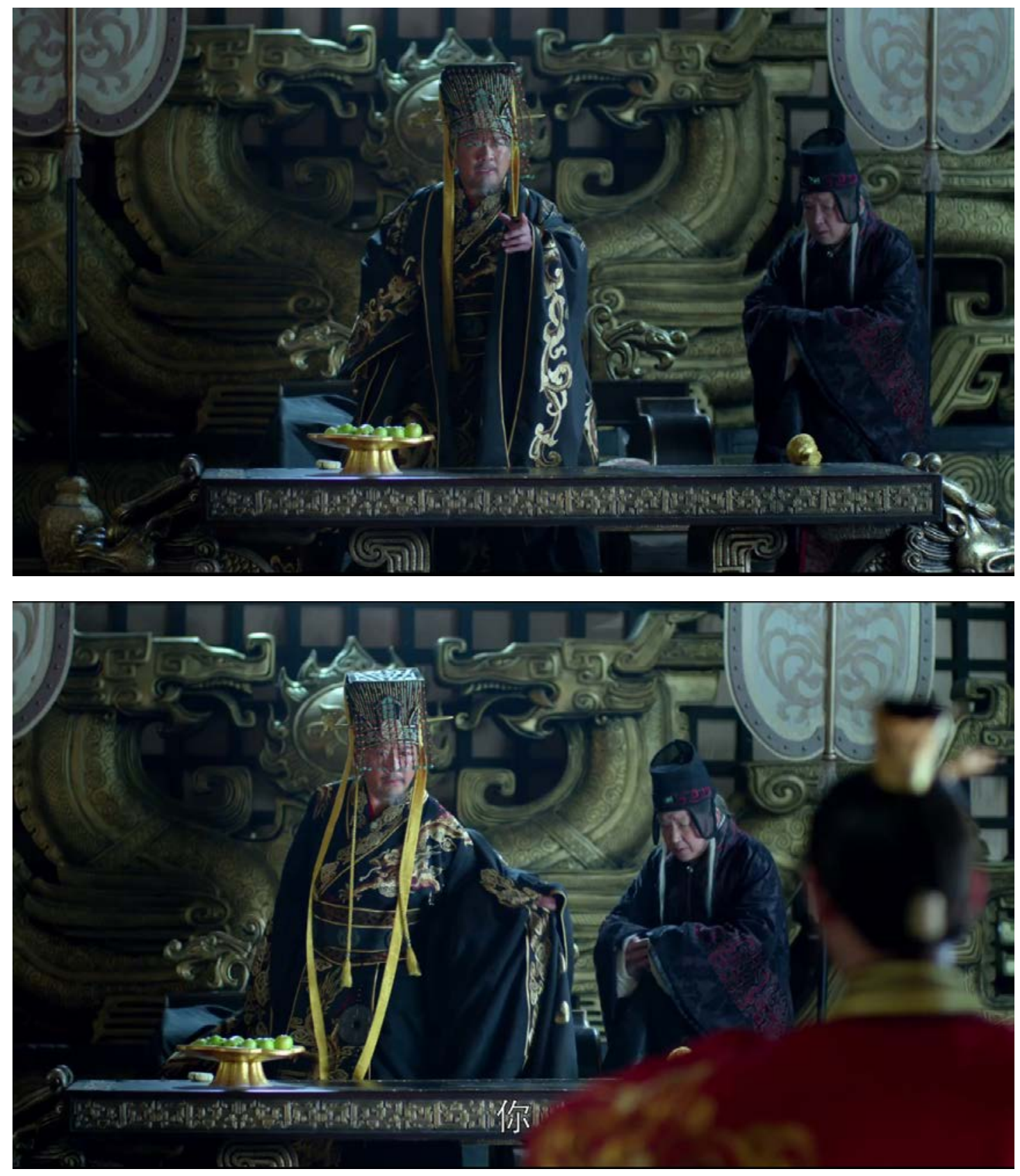
This is the accepted version of a forthcoming article that will be published by Taylor $\&$ Francis in Al-

Masaq: Journal of the Medieval Mediterranean: http://www.tandfonline.com/loi/calm20

Accepted Version Downloaded from SOAS Research Online: http://eprints.soas.ac.uk/24479/
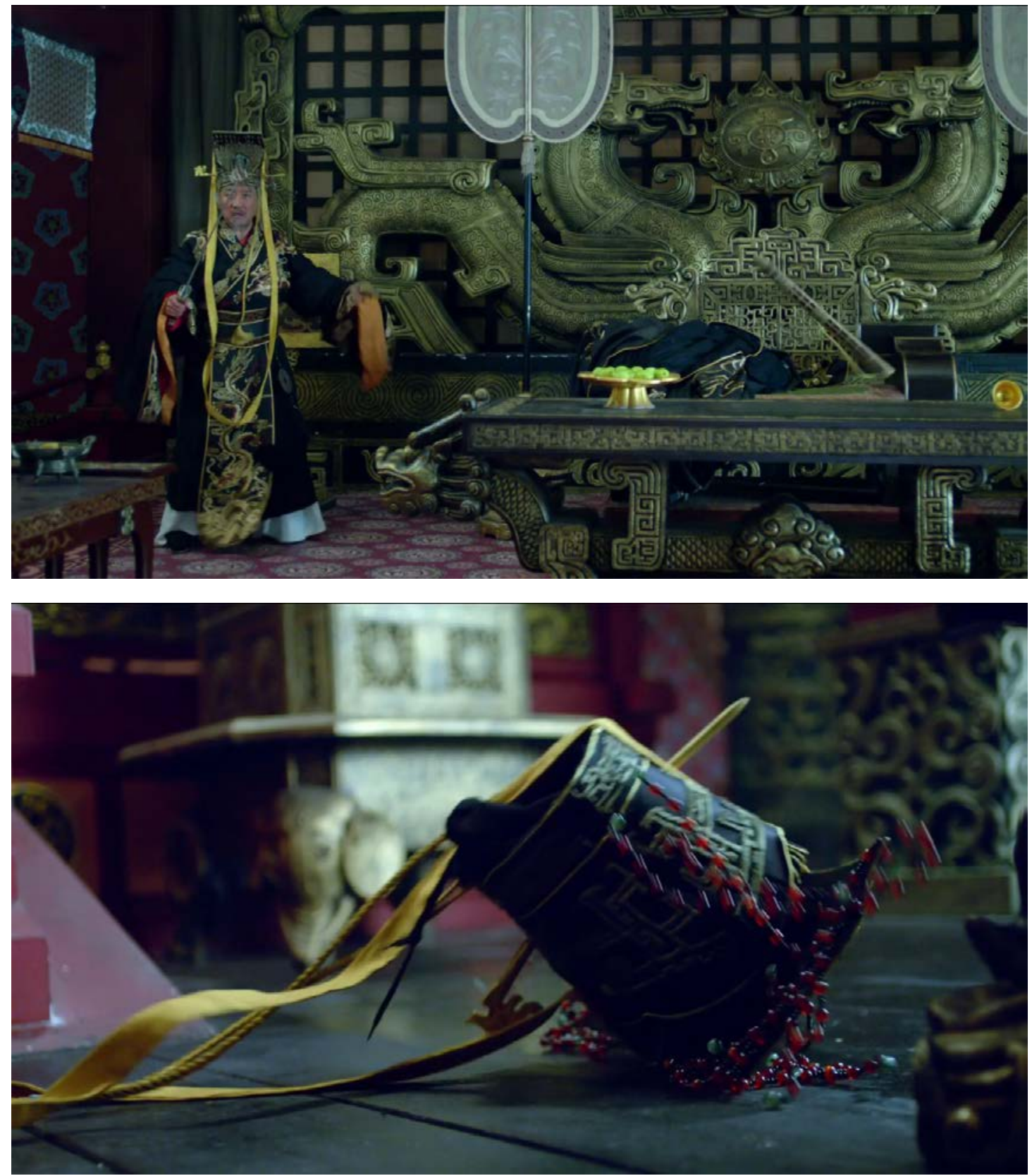

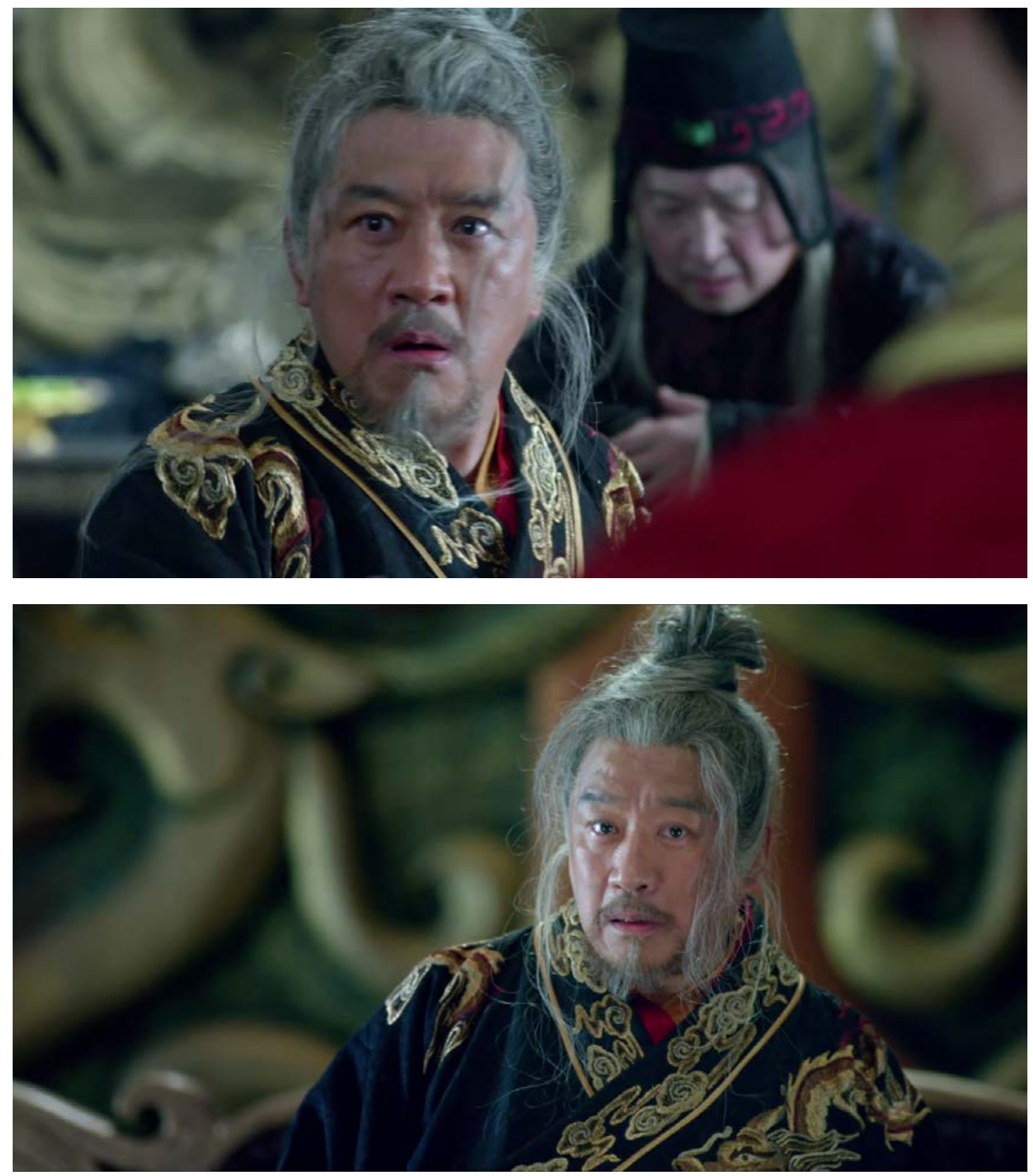

\section{Hair and Creativity in Poetry}

I want to take the two signs of loose hair as defeat, of human integrity and tyranny, in two semiological systems, one based in word and another in image, and overlap them to think about what these signs say about the semiological systems that inhere them. I now come to two details in the anecdotes about Jarīr and Majnūn in Kitāb al-aghānī. I make a link between what Jarīr does when he composes poetry, "fa ja cala yuhamhim," 42 and what Majnūn does when his father imprisons and shackles him at home (fahabisnāhu wa qayyadnāhu) only to let him free as he watches Majnūn bite his tongue and lips nonstop during captivity, "fa ja 'ala ya'uḍdu lisānahu wa shafatayhi," 43 and think of these as references to language as both the material for poetry and the structure that governs the intelligibility of language use in poetry. These go against the grain of theories of language-based communication in classical Arabic writings. Abū Sa īid al-Sīrāfī (d. 
368/978) famously collapsed Arabic grammar with Greek logic in al-Tawhīdī's (d. 414/2013) rendition of his debate with Mattā ibn Yūnus (d. 328/940), insisting that "[Arabic] grammar is logic derived from the Arabic language, and [Greek] logic is grammar comprehended in the [Greek] language (al-nahw manțiqun wa lākinnahu maslūkun min al- arabiyyah wa l-manțiq naḥwun wa lākinnahu mafümun fí l-lughah)," 44 and as such sees both logic, manțiq, the instrument of reason, ' $a q l$, and grammar, $n a h w$, the instrument of intelligibility in language, as structures of thought and instruments of communication. Intelligibility, therefore communication, is dependent on the ways in which meaning is conveyed through the grammatical or logical use of language. ${ }^{45}$ The structures of intelligibility, whether represented by grammar or logic, can be prisonhouses of thought and expression. The two details in the anecdotes on Jarīr and Majnūn mentioned above say as much.

In the first instance hamhamah points to the unintelligibility of what is uttered, or of utterance, and the second captivity frustrates the tongue, lisān, which denotes, whether in Arabic or English, both tongue and language. These two details, small as they are, brings us squarely into the field of literary production, and to the very heart of poetic creativity. What seems afoot here is that intelligibility of language, as based in the conventional use of it, is the tyranny of a semiology, let us call it 'aql for the moment, that holds creative forces captive in such a way as to lead to the destruction of the poet's tongue and language, his instrument and material. However, when 'aqlgives in to madness, junūn, whether in the form of perpetual insanity or temporary drunkenness, just as intelligibility, or grammaticality, or familiarity, gives way to unintelligibility, or ungrammaticality, or defamiliarization, the tight grip of any semiology opens up and out to lines of escape and creativity can happen, for only in creative use of language can the desired wonder effect, 'ajab, of poetry be achieved.

Hair, I would like to conclude, may be interpreted as a semiotic code underpinning Arabic theories of creativity in poetry. Its appearance in Kitāb alaghānīneed not be understood as intentional or accidental. Regardless, it signals that Arabic literary writings, perhaps all literary writings, theorize about the very process of their engagement with creativity even as they get creative. The legends of Majnūn are revealing in a most interesting fashion. As the possibility of a biography of a poet evaporates in the first section normally dedicated to genealogy in similar biographical compendia or dictionaries, when all the narrative threads meander in the footsteps of genealogical incoherence, and a definitive answer to the question, "who is Majnūn?" refuses to coalesce around a historical figure, the "Akhbār" on "Manjūn Banī 'Āmir" in Kitāb al-aghānī come to be readable as a treatise on poetry. Creativity in poetry is freedom from the familiar structures of language and purposes of normal communication; it thrives on ungrammaticality and defamiliarization. Paradoxically, it must at the same time inhere grammaticality and familiarity before it can break out of them into the world of wonder evocable only in poetry. This world of wonder is the ultimate object of desire of any literary writing. It is Majnūn's Laylā.

${ }^{1}$ Al-Iṣfahānī, Kitāb al-aghānī, 8: 22-24. 
2 Ibn al-Jawzī, Akhbār al-ḥamqā, 23.

3 Ibid.

4 Ibid.

5 Ibid.

6 Ibid.

7 Ibid, 32.

8 Ibn al-Jawzī, Dhamm al-hawā, 24.

${ }^{9}$ Ibn al-Jawzī, Akhbār al-hamqā, 30.

10 Ibid.

11 Ibid.

12 Ibid.

13 Ibid.

14 Ibid, 31.

15 Ibid.

16 Ibid.

17 Ibid.

18 Ibid.

19 Ibid.

20 Ibid.

${ }^{21}$ Al-muqtataf 21 (1): 24.

22 Ibid, 26.

23 Ibid, 26-27.

24 Ibid, 27.

25 Ibid.

26 Ibid.

27 Ibid, 30.

${ }^{28}$ Al-Ișfahānī, Kitāb al-aghānī, 2: 13.

29 Ibid, 11.

30 Ibid, 21.

31 Ibid, 11.

32 Ibid, 34, 43.

33 Ibid, 13.

34 Ibid, 14.

35 Ibid, 17.

36 Ibid, 43.

37 As'ad E. Khairallah, Love, Madness, and Poetry: an interpretation of the Mağnūn legend (Beirut, Wiesbaden: Orinet-Institut der Deutchen morgenländischen Gesellschaft, 1980).

${ }^{38}$ Al-Ișfahānī, Kitāb al-aghānī, 8: 23.

39 Ibid.

40 Ibid.

41 Ibid.

42 Ibid.

43 Ibid, 2: 57.

${ }^{44}$ Al-Tawhīdī, Al-imtā̄ wa l-mu’ānasah, 1:119.

${ }^{45}$ For further details, see Ouyang, "Literature and Thought." 